\title{
GERAKAN ISLAMIS DI SUMATERA BARAT PASCA ORDE BARU
}

\author{
Zainal \\ Fakultas Dakwah dan Ilmu Komunikasi IAIN Imam Bonjol \\ Jl. Prof. M. Yunus Lubuk Lintah, Padang, Sumatera Barat, 25153 \\ e-mail: zainaltkmudo@yahoo.com
}

\begin{abstract}
Abstrak: Gerakan Islamisme Radikalisme dalam Islam terlahir tidak hanya karena faktor pemahaman keagamaan yang literal terhadap ayat-ayat al-Qur'an atau faktor derivasi politik, sosial dan ekonomi saja, akan tetapi juga karena faktor bacaan yang kurang tepat terhadap sejarah Islam yang dikombinasikan dengan idealisasi berlebihan terhadap Islam pada masa tertentu. Tulisan ini mengungkap bagaimana faktor sejarah gerakan lokal berkontribusi pada memunculkan radikalisme. Kajian ini menggunakan pendekatan historis dengan memahami kronologis dan proses munculnya radikalisme Islam pasca Orde Baru di Sumatera Barat. Penulis berargumen bahwa kemunculan radikalisme Islam semakin terbuka, terlebih ketika dihadapkan pada keinginan pengulangan periode sejarah kejayaan Islam secara eksklusif, tanpa disertai kajian yang komprehensif tentang Islam dan masyarakat Muslim. Penulis juga menemukan bahwa gerakan radikalisme Islam di Sumatera Barat memiliki ketersambungan historis dengan gerakan Paderi abad ke-19.
\end{abstract}

\begin{abstract}
Islamist Movement in the Post-New Order Era West Sumatra. Islamist movement or radicalism emerges not only due to the literal understanding of verses of the Qur'an nor is it political, social and economic factors but it rather due to inappropriate reading of Islamic history combined with an excessive idealization of Islam in a given time. This writing tries to unveil how historical factor of local movement had contributed to the emergence of radicalism. This study uses a historical approach, by understanding the chronology and the process of the emergence of Islamic radicalism in the post-New Order West Sumatra. The writer argues that the emergence of Islamic radicalism is open even wider when it generated with the desire to repeat the period of Islamic glory without a comprehensive assessment of Islam and Muslim society. He also argues that Islamic radicalism movement in West Sumatra has a close historical bond with that of the $19^{\text {th }}$ century Paderi.
\end{abstract}

Kata Kunci: Islamisme, pergerakan Islam, radikal, Sumatera Barat 


\section{Pendahuluan}

Kemunculan gerakan Islam radikal di Indonesia tidak hanya fenomena sosial, politik dan teologi, tetapi juga merupakan potret kegagalan memahami dan memaknai sejarah dengan baik. Pernyataan ini senada dengan pendapat Khaled Abou El Fadl, ${ }^{1}$ dan Azyumardi Azra. ${ }^{2}$ Dalam konteks ini, tampaknya kelompok Islam radikal tidak berupaya menafsirkan sejarah sesuai dengan konteks zaman yang mengitarinya. Malah sebaliknya, mereka berkeinginan untuk mengembalikan sejarah sama seperti dahulunya, tanpa memberikan kritik konstruktif. Kekakuan memahami sejarah juga ikut andil memunculkan gerakan radikal. Menurut Robert Wuthnow upaya menerapkan sejarah yang telah berlalu apa adanya dengan zaman setelahnya disebut penemuan kembali atau rediscovery. ${ }^{3}$

Semenjak Islam radikal memperoleh momentum pasca runtuhnya rezim Soeharto (Orde Baru) yang dikenal otoriter, ${ }^{4}$ semangat menampilkan wajah Islam bercorak radikal semakin menguat, sehingga dengan itu kondisi sosial-keagamaan masyarakat mulai digeser. Hal ini ditandai dengan kemunculan berbagai organisasi masyarakat (selanjutnya disingkat ormas) Islam, baik yang berskala transnasional, nasional, maupun yang berskala lokal. Mereka gigih menyuarakan penampilan Islam secara ketat sama seperti pada masa Nabi. Di samping itu, kehadiran sejumlah ormas Islam baru tersebut, tampil dengan agresif, vokal dan mampu menyaingi ormas Islam yang telah lahir sebelumnya, seperti Muhammadiyah, Nahdlatul Ulama (NU), Persatuan Tarbiyah Islamiyah (Perti), Persatuan Islam (Persis), Washliyah, dan organisasi Islam lainnya, sehingga menurut Abdurrahman Wahid (GusDur), ormas Islam arus-utama yang selama ini telah eksis mulai "tenggelam".

Ormas Islam baru yang hadir belakangan ini, pada umumnya menguatkan ideologi religious extremism. Mereka cenderung mendominasi perubahan dalam kehidupan sosial, agama, dan politik di Indonesia, seperti meluasnya aspirasi formalisasi syariat Islam, dan kuatnya keinginan mendirikan Negara Islam. Di samping itu, ekspresi Islam juga menunjukkan perubahan wajah, semula bersifat ramah dan toleran kemudian berubah menjadi menakutkan dan militan. ${ }^{5}$ Kenyataan ini terbukti dengan sejumlah peristiwa yang menimpa Indonesia, seperti pemboman di Bali, di Solo, di Jakarta, dan tempat lainnya. Peristiwa ini, menjadikan

${ }^{1}$ Khaled Abou El Fadl, The Great Theft: Wrestling Islam from the Extrimism (San Francisco: Harper Collins Publishers, 2005), h. 131.

${ }^{2}$ Azyumardi Azra, Pergolakan Politik Islam dari Fundamentalisme, Modernisme hingga Post-Modernisme (Jakarta: Paramadina, 1996), h. 185.

${ }^{3}$ Robert Wuthnow, Rediscovering the Sacred: Perspective on Religion in Contemporary Society (Eerdmans: Michigan, 1992), h. 1-5.

${ }^{4}$ Mona Abaza, "Generasi Baru Mahasiswa Indonesia di Al-Azhar", Islamika, No. JanuariMaret (1994), h. 37-38.

${ }^{5}$ Nurcholis Madjid, Islam Agama Peradaban: Mencari Makna dan Relevansi Doktrin Islam dalam Sejarah (Jakarta: Paramadina, 1995), h. 260. 
penilaian yang tidak "sedap" terhadap Islam, ${ }^{6}$ sehingga menurut Deliar Noer ${ }^{7}$ semakin banyak istilah yang dilontarkan, seperti istilah Islam militan, Islam radikal, Islam fundamental, Islam liberal, Islam ekstrem, Islam politik (kebalikan Islam kultural), Islam eksklusif, Islam substanstif, dan banyak lagi istilah lain. ${ }^{8}$

Sementara itu, ormas Islam yang lahir setelah Orde Baru sering mengekspresikan Islam, seperti kriteria radikal yang akan dikemukakan di bawah ini. Kemudian pada saat yang sama, ormas Islam yang telah disebutkan di atas menunjukkan perkembangan yang cukup pesat di beberapa wilayah Indonesia, termasuk di Sumatera Barat. Tentu dengan sendirinya akan memunculkan permasalahan di tengah kehidupan masyarakat yang tidak akrab atau tidak lazim menyaksikan ekspresi Islam seperti demikian. Menurut Ted Robert Gurr, semua bentuk radikal adalah ancaman yang mesti ditakuti termasuk radikalisasi kelompok-kelompok komunal Muslim. ${ }^{9}$

Ormas Islam berhaluan keras ini, juga berkembang di Sumatera Barat dengan segala pemikiran dan gerakannya. Sebagai wilayah yang menganut falsafah "Adat Basandi Syarak, Syarak Basandi Kitabullah", sejatinya kelompok Muslim Sumatera Barat cukup selektif menerima dan mengembangkan paham/pemikiran dan gerakan yang bertolak belakang dengan Islam arus-utama di sana. Tetapi kenyataannya ormas Islam baru ini, cukup leluasa menumbuhkan pemikiran dan gerakan Islam yang berhaluan radikal.

\section{Awal Gerakan Islam Radikal di Indonesia}

Dalam teori yang dikenal dengan istilah "pengulangan sejarah" cukup mendukung kemunculan radikalisme Islam di Sumatera Barat, karena ia dipengaruhi oleh peristiwa radikal sebelumnya. Dalam catatan sejarah, Sumatera Barat pernah mengalami radikalisasi agama pada tempo dulu. Pada konteks ini, gerakan radikalisme Islam di Sumatera Barat bukan sebuah fenomena yang baru, melainkan ia pernah tumbuh dan berkembang pada abad ke-19 yang dikomandoi oleh gerakan Paderi, gerakan awal radikalisme Islam di Indonesia. ${ }^{10}$

Meskipun kemunculan radikalisme Islam di Sumatera Barat setelah runtuhnya rezim

${ }^{6}$ Nurcholis Madjid, Pintu-Pintu Menuju Tuhan (Jakarta: Paramadina, 1995), h. 270.

${ }^{7}$ Deliar Noer sebuah kata pengantar dalam Khamami Zada, Islam Radikal Pergulatan OrmasOrmas Islam Garis Keras di Indonesia (Jakarta: Teraju, 2002), h. xiii.

${ }^{8}$ Islam militan adalah label yang diberikan pada kelompok Muslim yang memiliki semangat tinggi dalam beragama. Informasi lebih lanjut dapat dilihat G.H. Jansen, Militant Islam, terj. Armahedi Mahzar (Bandung: Pustaka, 1980), h. 47.

${ }^{9}$ Ted Robert Gurr, "Minorities, Nationalists, And Islamists: Managing Communal Conflict in The Twenty-First Century, dalam Leashing the Dogs of War: Conflict Management in a Divided World (USA: USIP Press, 2008), h. 136.

${ }^{10}$ Informasi lebih jelas lihat Azyumardi Azra, Jaringan Ulama Timur Tengah dan Kepulauan Nusantara Abad XVII \& XVIII Akar Pembaruan Islam Indonesia (Jakarta: Kencana, 2007), xviii, untuk mendapatkan perbandingan lihat juga Christine Dobbin, Gejolak Ekonomi, Kebangkitan Islam, dan Gerakan Paderi Minangkabau 1784-1847 (Depok: Komunitas Bambu, 2008), h. 204. 
Orbe Baru adalah momentum kebebasan berpikir dan menyatakan pendapat seperti yang digerakan oleh sejumlah ormas "Islam Baru", ${ }^{11}$ namun kuat dugaan bahwa ini masih ada terkait dengan gerakan Paderi dari segi pemikiran dan gerakan. ${ }^{12}$ Artinya ada keinginan mereka untuk mengulangi kembali gerakan Paderi pada saat sekarang.

Kehadiran sejumlah ormas Islam baru ini membawa ciri-ciri khusus yang berbeda dari ormas Islam yang telah ada, seperti dari segi penampilan mereka memakai baju koko putih yang dipasang dengan celana hitam di atas mata kaki, bersorban atau berpeci, dan memelihara jenggot. ${ }^{13}$ Kemudian dari strategi menyalurkan tuntutan seperti pemberlakuan syariat Islam, mendirikan khilafah Islamiyah dan pelarangan perbuatan munkar. Mereka tidak jarang melakukan aksi-aksi kekerasan, bahkan kadangkala mereka tidak mengenal kompromi. Tampaknya penggunaan kekerasan sudah menjadi karakteristik gerakan kelompok ini, sehingga mereka sulit terlepas dari sebutan "radikal", "militan", atau bahkan "ekstrem". ${ }^{14}$ Pada konteks ini mereka memiliki banyak kemiripan dengan yang telah ditampilkan kelompok Paderi pada abad ke-19 dulu, baik dari segi simbol, pemikiran, dan gerakan.

Pada saat yang sama dalam skala global, sorotan terhadap radikalisme Islam di Indonesia termasuk Sumatera Barat juga menjadi perbincangan dunia, seperti yang diungkapkan oleh Lee Kuan Yew, menteri senior Singapura, bahwa radikalisme Islam di Indonesia merupakan sel-sel teroris yang mempunyai hubungan dengan terorisme internasional. Tentu pernyataan ini telah mendiskreditkan gerakan-gerakan Islam di Indonesia. Demikian juga halnya dengan perlakuan pemerintah Filipina yang menangkap aktivis Islam Indonesia sewaktu berkunjung ke sana, seperti Tamsil Linrung (tokoh ICMI) dan Agus Dwi Karna (Ketua Jundullah). ${ }^{15}$ Kuat dugaan asumsi dan perlakuan demikian dikaitkan dengan sejumlah peristiwa pemboman yang terjadi di Indonesia seperti di Bali pada 12 Oktober 2002 yang beriringan dengan peristiwa pemboman di gedung WTC Amerika Serikat pada 11 September 2001.

Meskipun ada beberapa pandangan menyebutkan bahwa kondisi seperti disebut di atas dipengaruhi oleh realitas politik domestik dan internasional yang telah menyudutkan Islam, yang pada akhirnya menimbulkan perlawanan dengan cara radikal melalui gagasan

\footnotetext{
${ }^{11}$ Kelompok "Islam Baru" dalam konteks ini adalah Lasykar Jihad, Majelis Mujahidin Indonesia, Hizbut Tahrir Indonesia, Front Pembela Islam, Salafi, Kelompok-kelompok Tarbiyah (yang kemudian menjadi Partai Keadilan Sejahtera). Meminjam istilah Imdadun Rahmat, kelompok Islam Baru ini disebut "aktor baru" yang memiliki agenda di luar arus-utama kelompok Islam sebelumnya. Lihat M. Imdadun Rahmat, Arus Baru Islam Radikal: Transmisi Revivalisme Islam Timur Tengah ke-Indonesia (Jakarta: Erlangga, 2005), h. x.

${ }^{12}$ Michael Laffan, The Makings of Indonesian Islam: Orientalisme and the Narration of a Sufi Past ( New Jersey: Princeton University Press, 2011), h. 44.

${ }^{13}$ Jeffrey Hadler, Sengketa Tiada Putus Matriarkat, Reformisme Islam, dan Kolonialisme di Minangkabau (Jakarta: Freedom Institute, 2008), h. 35.

${ }^{14}$ Jamhari \& Jajang Jahroni, Gerakan Salafi Radikal di Indonesia (Jakarta: Grafindo Persada, 2004), h. v-vi.

${ }^{15}$ Endang Turmudi, et al., Islam dan Radikalisme di Indonesia (Jakarta: LIPI Press, 2005), h. 4. 
kebangkitan Islam, namun tetap ada pengaruh akar sejarah radikalisme Islam yang pernah dialami Indonesia, khusus Sumatera Barat. Dalam konteks Sumatera Barat masalah radikalisme Islam sudah semakin membesar karena jumlah pendukungnya juga bertambah. Hal ini ditunjukkan oleh semakin tingginya partisipasi masyarakat mengikuti kegiatan kelompok Hizbut Tahrir, ${ }^{16}$ dan Komite Penegak Syariat Islam. ${ }^{17}$ Mencermati radikalisme Islam di Sumatera Barat, ${ }^{18}$ terlihat pada fenomena yang muncul belakangan ini, yaitu tampil Hizbut Tahrir, Salafi, Front Pembela Islam (FPI), Komite Penegak Syariat Islam di Sumatera Barat untuk mengembangkan ideologi religious extremism. Di samping itu, radikalisme Islam juga ditunjukkan oleh sejumlah peristiwa yang tidak lazim terjadi sebelumnya, melakukan tindakan kekerasan pada beberapa tempat yang ditengarai sarang maksiat, ${ }^{19}$ serta penolakan secara keras terhadap M. Atho Mudzhar sebagai Pelaksana Tugas Rektor IAIN Imam Bonjol Padang tahun akhir 2006 karena dianggap liberal, dan lebih mengkhawatirkan lagi muncul isu pemboman "Jam Gadang" di Bukittinggi serta tertangkapnya Beni Asri di Kota Solok sebagai salah seorang pelaku bom bunuh diri pada 15 April 2011 di Mesjid Polres Cirebon. ${ }^{20}$ Lebih nyata lagi tertembaknya Ediar Amin (putra Kampung Pauh, V Koto Kampung Dalam, PadangPariaman) sebagai salah seorang terduga terorisme oleh Densus 88 Polri pada saat pergantian tahun 2014 di Ciputat, Tangerang Selatan, Banten. ${ }^{21}$

Fakta ini cukup menguatkan bahwa radikalisme Islam mulai bangkit di Sumatera Barat, seperti yang dikemukakan oleh Karen Armstrong, bahwa radikalisme agama itu bisa terjadi di mana pun dan oleh agama apa pun, hanya saja kadar dan bentuknya yang berbeda. ${ }^{22}$ Radikalisme sesungguhnya tidak merupakan masalah, sejauh ia hanya dalam

${ }^{16}$ Hizbut Tahrir Sumatera Barat mengadakan kegiatan Tabligh Akbar yang diikuti oleh 4.000 jama'ah pada tanggal 26 Mei 2013 di Mesjid Raya Sumatera Barat. Pada kegiatan ini banyak mendapat respons positif masyarakat. Dengan motto kegiatan mereka adalah "pengokohan kembali pendirian khilafah Islamiyah". Tentu dengan gejala seperti ini, semakin menunjukkan bahwa paham radikalisme mendapat sambutan oleh masyarakat Sumatera Barat.

${ }^{17}$ Pada tanggal 18 April 2013, Komite Penegak Syariat Islam (KPSI) berhasil mendorong Pemko Padang merazia, menangkap, dan membubarkan kegiatan penyakit masyarakat, seperti karaoke di kafe pinggir pantai Padang dengan cara yang radikal.

${ }^{18}$ Terungkap ketika Fakultas Dakwah IAIN Imam Bonjol Padang menyelenggarakan Seminar Nasional pada tanggal 3 November 2012 di Padang dengan tema "Dakwah dan Radikalisme". Dikutip dari Surat Kabar Harian Padang Ekspres, Sabtu, 3 November 2012.

${ }^{19}$ Seperti sejumlah pinggiran pantai Kota Padang, Pantai Caroline di Bungus, dan tempat lainnya atau beberapa kafe yang dianggap sering digunakan tempat minum-minuman memabukkan, dan perbuatan melanggar lainnya.

${ }^{20}$ Beni Asri bersama empat rekannya, Nanang Irawan, Pino Damayanto, Heru Komaruddin, dan Yadi Supriyadi, juga terlibat sebagai perakit bom pada kasus bom bunuh diri di Masjid Az-Zikra, Markas Polres Cirebon Kota, Jawa Barat, dan sebagai pengeboman di Gereja Bethel Injil Sepenuh, Kepunton, Solo, pada 25 September 2011. http://www.tempo.co/read/news/2011/10/21/ 063362677/Inilah-yang-Ditangkap-dalam-Kasus-Bom-Cirebon. Diakses tanggal tgl 15 November 2012.

${ }^{21}$ Koran Harian Umum Singgalang, Senin, 6 Januari 2014, 1 \& 11.

${ }^{22}$ Lihat Karen Armstrong, the Buttle for God, Terjemahan. Satrio Wahono dan Abdullah Ali (Bandung: Mizan, 2001), h. xiii. Bandingkan dengan William Shepard, "Fundamentalism Christian and Islamic," Religion 17 (1987), h. 355-378. 
tataran pemikiran (ideologi) para penganutnya. Tetapi ketika radikalisme pemikiran bergeser menjadi gerakan-gerakan radikal maka ia mulai menimbulkan masalah, terutama ketika harapan mereka untuk merealisasikan pemikiran tersebut terhambat oleh kekuatan yang ada. Dalam situasi seperti demikian radikalisme cenderung akan diiringi oleh tindak kekerasan, sehingga fenomena ini berpotensi menimbulkan konflik terbuka atau bahkan kekerasan antara kedua kelompok yang berhadapan. ${ }^{23}$

\section{Perbedaan Pandangan dalam Mencermati Islam Radikal}

Perbincangan tentang radikalisme Islam di Sumatera Barat pasca Orde Baru masih termasuk kajian yang langka bahkan hampir tidak ditemukan fokus penelitian tentang radikalisme Islam di Sumatera Barat. Penyebabnya cukup banyak, namun yang penting dikemukakan di sini adalah ada pendapat yang menyatakan bahwa kadar radikalisme Islam di Sumatera Barat belum sederas radikalisme Islam di Jakarta dan Jawa, sehingga ditengarai pembahasan tentang radikalisme Islam di Sumatera Barat tidak begitu menarik. Nampaknya pendapat ini lupa terhadap pengalaman pahit yang pernah menimpa Sumatera Barat dengan berbagai peristiwa kekerasan, seperti peristiwa gerakan Paderi pada abad ke-19, peristiwa perang Kamang pada awal abad ke-20, dan PRRI di penghujung abad ke20. Peristiwa tersebut memang tidak semuanya yang murni bermotif agama, namun paling tidak, ada kecenderungan menjadikan agama sebagai penguat kejadiannya, sehingga cukup berpotensi Sumatera Barat sebagai basis Islam radikal setelah Jakarta dan Jawa. Oleh karena itu dapat dimaklumi belum banyak penelitian yang ditemukan menyorot tentang radikalisme Islam di Sumatera Barat. Hal ini termasuk salah satu faktor yang mendorong peneliti menjatuhkan pilihan pada tema ini.

Sampai sekarang, penggunaan kata radikal terhadap Islam masih dalam wilayah perdebatan, karena dengan kata radikal terkesan mengaburkan makna dasar Islam. Secara generik "Islam" berarti "tunduk", "damai", "keselamatan", dan seterusnya. Sedangkan radikal dikonotasikan kebalikan dari kata Islam, seperti yang diungkap oleh Amien Rais radikal adalah suatu sikap atau posisi dengan menggunakan ideologi atas nama agama untuk melakukan sebuah perubahan kepada sesuatu yang baru dengan cara kekerasan (violence) dan aksi-aksi yang ekstrem tanpa mempertimbangkan nilai-nilai yang telah ada. ${ }^{24}$ Pada konteks ini makna normatif Islam seakan terkikis oleh perilaku penganutnya yang menyimpang.

Pelabelan Islam dengan kata radikal mendatangkan pro dan kontra, ${ }^{25}$ baik dari kalangan Islam maupun dari luar kalangan Islam, sehingga terdapat banyak istilah dalam penyebutan

${ }^{23}$ Endang Turmudi, et al., Islam dan Radikalisme di Indonesia, h. 4.

${ }^{24}$ Lihat Amien Rais, Cakrawala Islam (Bandung: Mizan, 1995), h. 132.

${ }^{25}$ Karena umumnya kata yang senada dengan radikal ini seperti "terorisme", "fundamentalisme", "militanisme" dan "ektremisme" pada umumnya dipopulerkan oleh para pakar sosial-politik Barat, sehingga pengaruh subjekivitasnya sulit terlepas. Lihat Riza Sihbudi, "Dimensi Internasional Terorisme", makalah (Pamulang 6 Desember 2005), h. 1-2. 
Islam pada konteks radikal ini. Istilah yang dimunculkan para ahli dalam menyorot ekspresi Islam berhaluan radikal, paling tidak terdapat empat nama, tetapi beberapa istilah itu masih memiliki kemiripan makna dengan radikalisme dan terorisme.

Pertama adalah istilah fundamentalisme. Istilah ini digunakan Martin Riesebrodt dalam tulisannya "Fundamentalism and the Resurgence of Religion" 26 dalam menyorot sikap dan perilaku kelompok masyarakat yang menggunakan tindak kekerasan dalam menyalurkan pemikiran dan aspirasinya, tanpa mempertimbangkan aspek realitas yang mengitarinya. Artinya kelompok masyarakat seperti ini, hanya menggunakan teks agama apa adanya tanpa dibarengi dengan penafsiran yang logis dalam menjawab permasalahan yang terjadi. Demikian juga halnya Olivier Roy $^{27}$ dalam karyanya The Failure of Political Islam juga menggunakan kata fundamentalisme untuk mencermati Islam berhaluan keras. Pendapat yang sama juga dikemukakan oleh Ernest Gellner ${ }^{28}$ dan Samuel P. Huntington ${ }^{29}$ yang juga menggunakan istilah fundamentalisme dalam melabeli kelompok yang bergaris keras. Sementara itu, Bassam Tibi yang juga menggunakan istilah fundamentalisme, dalam hal ini ia menyebut istilah fundamentalisme Islam dengan Usuliyyah al-Islamiyyah. Di dunia Arab istilah fundamentalisme lebih dikenal dengan nama "al-Islam al-Siyasi", karena kelompok Muslim di sana memahami Islam bukan sebagai keimanan atau sistem etika, tetapi lebih sebagai ideologi politik. ${ }^{30}$ Dalam tradisi pemikiran teologi keagamaan, fundamentalisme merupakan salah satu gerakan yang berusaha untuk mengembalikan seluruh perilaku dan tatanan kehidupan umat Islam kepada Al-Qur'an dan Hadis. ${ }^{31}$

Pemakaian kata fundamentalisme dalam Islam tidak lazim digunakan, karena terkesan menyamakan permasalahan yang dialami Islam dengan Kristen. Pemakaian kata fundamentalisme ini lebih melekat pada kalangan Kristen dibandingkan dengan Islam, sebab pertama kali kata ini dipakai untuk melabeli kelompok Kristen yang ortodoks atau menolak segala bentuk aktivitas rasionalitas. Kemudian istilah itu dipasangkan kepada Islam oleh para pengamat dalam menganalisis dinamika Islam kontemporer. Pada umumnya mereka yang memberikan istilah demikian kepada Islam banyak berasal dari kalangan Kristen.

Dalam pandangan Karen Armstrong, gerakan fundamentalisme tidak hanya terdapat pada agama Islam dan Kristen saja, tetapi fundamentalisme juga ada pada agama Budha,

${ }^{26}$ Martin Riesebrodt, "Fundamentalism and the Resurgence of Religion", Jestor Numen. Vol. 47, Fase 3 (2000), h. 266-279.

${ }^{27}$ Olivier Roy, The Failure of Political Islam (London: President and Fellows of Havard, 1994), h. 62.

${ }^{28}$ Ernest Gellner, Muslim Society (Cambridge: Cambridge University, 1984), 49-51.

${ }^{29}$ Samuel P. Huntington, “The Clash of Civilization?”, Affair, Vol. 72, No. 3 (Summer 1993, 1996), h. 23-25.

${ }^{30}$ Bassam Tibi, "Islamisme, Demokrasi, and the Clash of Civilization", dalam Chaider S. Bamualim (ed.), Islam \& The West (Jakarta: Pusat Bahasa dan Budaya UIN, 2003), h. 17.

${ }^{31}$ William Montgmery Watt, Islamic Fundamentalism and Modernity (London: T.J. Press (Padstow) Ltd, 1998), h. 2. 
Hindu dan bahkan Kong Hu Cu. Pada intinya semua agama yang telah disebutkan di atas sama-sama menolak butir-butir nilai budaya liberal, saling berperang atas nama agama (Tuhan) dan berusaha membawa hal-hal yang sakral ke dalam urusan politik dan negara. ${ }^{32}$

John Obert Voll sependapat dengan Muhammad Sa'id al-Ashmawi, ${ }^{33}$ dalam hal pengelompokan fundamentalisme, hanya saja redaksinya yang berbeda, al-Ashmawi menyebutnya dengan aktivis political fundamentalism dan rational spritualis fundamentalism. ${ }^{34}$ Sedangkan John Obert Voll menamakannya dengan fundamentalism tradisionalism dan fundamentalism radikalism. Sesungguhnya kedua pendapat ini sama menyatakan, pertama: bahwa fundamentalisme ada yang terinfiltrasi kepada kelompok yang memperjuangkan Islam sebagai kekuatan politik, contohnya adalah kelompok Islam yang merujuk pada al-Khawarij yang pada saat itu menghendaki hukum sebagai landasan politik. Kedua: fundamentalisme yang terinfiltrasi oleh keinginan kembali kepada Al-Qur'an dan tradisi sebagaimana yang dipraktikkan oleh generasi Muslim pertama.

Kedua, adalah istilah radikalisme. Beberapa tokoh berpendapat bahwa radikal adalah suatu gerakan yang dilakukan oleh kelompok tertentu untuk mengganti tatanan yang sudah ada dengan keyakinan yang mereka anggap benar (menarik-narik ajaran agama) dengan sikap emosional yang menjurus keras dan anarkis. Lebih tegas lagi diungkapkan bahwa radikalisme ini dapat dilihat pada dua lapis; pertama, kekerasan dan manipulasi untuk membenarkan radikalisme dengan mengutip doktrin-doktrin Islam tertentu, sehingga logis kekerasan dapat muncul karena interpretasi secara literal terhadap Islam. Kedua, penggunaan kekerasan melakukan perubahan sudah dapat dipastikan bertolak belakang dengan nilai-nilai Islam. ${ }^{35}$

Radikalisme Islam, secara bahasa, radikalisme berawal dari kata radikal yang berasal dari kata "radic" mempunyai arti perubahan secara mendasar dan prinsip. Dapat dipahami radikal adalah sebuah tingkah laku yang menjurus keras, radikalis adalah orang yang melakukan tindak kekerasan, sedangkan radikalisme adalah sifatnya yang terlahir dari radikal. Menurut Sartono Kartodirjo seorang sejarawan menyebutkan pemakaian kata "radikal" sering digunakan sebagai indikator sikap penolakan total terhadap seluruh kondisi yang ada dengan menggunakan simbol agama. ${ }^{36}$

${ }^{32}$ Karen Armstrong, The Battle for God (New York: Knopf, 2000), h. 9-12. Edisi terjemahnya lihat Karen Armstrong, Berperang Demi Tuhan, terj. Sutrisno Wahono dkk (Jakarta Bandung: Kerjasama Serambi dengan Mizan, 2001), h. x.

${ }^{33}$ Muhammad Sa'id al-Ashmawi, Ushul al-Syari'ah, cet. Ke-4 (Kairo: al-Maktabah Madbuli al-Shagir, 1996), h. 105.

${ }^{34}$ Penjelasannya dapat dilihat dalam Muhammad Sa'id al-Ashmawi, Islam and the Political Orderi (Washington, DC: CRVP, 1994), h. 8.

${ }^{35}$ Azyumardi Azra, "Revisitasi Islam Politik dan Islam Kultural Indonesia" dalam Jurnal Indo-Islamika, Vol. 1, Nomor 2, (2012), h. 240.

${ }^{36}$ Dapat ditinjau dalam beberapa karyanya seperti: Sartono Kartodirdjo, Protest Movements in Rural Java (Singapore: Oxford University Press, 1973). Lihat juga karyanya yang lain, Ratu Adil (Jakarta: Sinar Harapan, 1992). 
Menurut John L. Esposito ideologi Islam radikal atau dengan istilah lainnya "Islam Revivalis" memiliki kecenderungan sebagai berikut: pertama, kelompok-kelompok ini berpendapat bahwa Islam adalah sebuah pandangan hidup yang komprehensif dan bersifat total, sehingga Islam tidak bisa dipisahkan dari kehidupan politik, hukum dan masyarakat, kedua, mereka sering menganggap bahwa ideologi masyarakat Barat yang sekuler dan cenderung materialistis harus ditolak. Masyarakat Muslim tidak mampu membangun masyarakat beragama ideal yang sesuai jalan lurus, malah mengikuti cara pandang Barat yang sekuler dan materialistis. Ketiga, mereka cenderung mengajak pengikutnya untuk kembali kepada Islam sebagai sebuah usaha untuk perubahan sosial. Perubahan harus merujuk Al-Qur'an dan Hadis sepenuhnya. Keempat, peradaban dan peraturan yang dari Barat harus ditolak karena ideologinya jauh menyimpang dari Islam dan sebagai gantinya masyarakat Muslim harus menegakkan hukum Islam sebagai satu-satunya sumber hukum yang diterima. Kelima, terlalu mengagungkan kejayaan Islam di masa lalu, dan keenam, mereka berkeyakinan bahwa upaya-upaya Islamisasi pada masyarakat Muslim tidak akan berhasil tanpa menegakkan aspek perorganisasian atau pun pembentukan sebuah kelompok yang kuat. ${ }^{37}$

Olivier Roy menambahkan akar radikalisme didorong oleh tiga hal: pertama, kesombongan intelektual dengan memutlakkan kebenaran pandangan sendiri (absolutisme), kedua, kesombongan sosial berupa sikap tertutup dan tidak mau berdialog dengan pihak lain (eksklusivisme), ${ }^{38}$ dan ketiga, kesombongan emosional berupa sikap yang fanatik pada pandangan sendiri (fanatisme). Kenyataan yang ditangkap bahwa kekerasan yang menjurus radikal adalah ekspresi kelompok Islam eksklusivisme yang tidak mampu menerima perbedaan yang ada. Hal ini cukup beralasan mereka disebut radikal apabila berkaca pada kejadian yang mengatasnamakan Islam seperti kasus-kasus kekerasan, padahal Islam tidak sempit seperti yang mereka pahami. ${ }^{39}$

Berpijak pada penjelasan di atas dapat dikatakan bahwa sesungguhnya penyebutan Islam dengan istilah "Islam radikal" tidak lain merupakan sebuah kesatuan dari berbagai fenomena sosial dan keagamaan kelompok-kelompok Muslim yang sedemikian kompleks. Pada tataran ini, pemakaian kata radikal, seperti yang dikemukakan Jamhari hanya ditujukan sebuah titik tolak (point of departure) ketimbang sebagai sebuah penjulukan, pelabelan yang mapan dan tidak berubah terhadap fenomena tersebut. Menurut Jamhari penyebutan

${ }^{37}$ John L. Esposito, The Islamic Theart Myth or Reality? (Oxford: Oxford University, 1992), h. 98 .

${ }^{38}$ Menurut Woodward kecenderungan eksklusif ini sering menjadi alasan membela dan menjaga kesucian agama (ideologi tertutup dan eksklusif) menyebabkan mereka kehilangan akal sehat untuk berpikir lebih jernih, sehingga tindakan terror dan sejenisnya dianggap jalan yang tepat. Lihat Mark R. Woodward (ed.), Jalan Baru Islam, Memetakan Paradigma Mutakhir Islam Indonesia. Terj. Ihsan Ali Fauzi (Bandung: Mizan, 1999), h. 31.

${ }^{39}$ Olivier Roy, The Failure of Political Islam, trans. Carol Volk (Cambridge, Massachusetts: Harvard University Press, 1994), h. 12 \& 75. 
label demikian tidak sepenuhnya menampilkan keberagaman gerakan-gerakan tersebut, di samping ia hanya bagian diskursus kehidupan sosial politik dan keagamaan kontemporer. ${ }^{40}$

Ketiga, istilah berikutnya adalah "militan", seperti yang dikemukakan oleh G. H. Jansen dalam buku Militant Islam, ${ }^{41}$ begitu juga dengan Adam Schwarz melalui karyanya A Nation in Waiting: Indonesia Search for Stability, ${ }^{42}$ ketika mencermati gerakan Islam yang diekspresikan oleh organisasi DDII dan KISDI. Argumen yang dikemukakan oleh masing-masing ini adalah: bahwa kedua organisasi itu sangat kaku dalam menafsirkan hukum, bersikap anti-Barat beserta bagiannya, dan merasa tidak senang terhadap etnis China, dan umat Kristen. Selain Jansen, Lee Kuan Yew juga menggunakan militan, ketika mengamati kelompok "ekstrem". 43

Sementara itu Yusuf Qardawi termasuk cukup hati-hati dalam menyebut kelompok Muslim yang peduli terhadap agamanya, sebagai bentuk sikap ekstrem. Ia memberikan analisis, bahwa seseorang yang kuat pendidikan agamanya dan dibesarkan dalam lingkungan yang kuat berpegang pada agama, niscaya perasaannya menjadi amat peka setiap kali melihat pelanggaran atau pengabaian yang bagaimanapun terhadap agama. Ia akan merasa heran bila melihat seorang Muslim tidak pernah mendirikan shalat wajib, shalat malam atau puasa sunnah di siang harinya. Oleh sebab itu menurut Qaradawi tidak cocok label ekstrem dilekatkan terhadap Muslim seperti ini. ${ }^{44}$

Dalam hal ini, Yusuf Qardawi menjelaskan ciri-ciri ekstrem sebagai berikut: pertama, fanatik pada suatu pendapat dan tidak mengakui pendapat-pendapat lain. Sikap seperti ini merupakan cerminan dari fanatisme yang keterlaluan sehingga tidak ada ruang kompromi, yang menyebabkan tidak ada yang benar kecuali dirinya sendiri. Fanatisme seperti itu sangat dicela, yang hanya mengakui dirinya sendiri berada pada pihak yang benar, sementara menafikan dan menolak orang lain. Kedua, mewajibkan diri sendiri dan orang lain pada sesuatu yang tidak diwajibkan Allah. Kelompok ini adalah orang yang memiliki paham memberatkan diri sendiri dan diri orang di tengah ketidakmampuannya mengerjakan sesuatu itu, padahal di dalamnya telah diberikan kemudahan untuk mengerjakannya. Ketiga, memperberat yang tidak pada tempatnya. Maksudnya di sini adalah meletakkan sesuatu pada proporsi yang tidak sesuai dengan tempat dan zamannya; seperti melakukannya

\footnotetext{
${ }^{40}$ Jamhari dan Jajang Jahroni (Penyunting), Gerakan Salafi Radikal di Indonesia (Jakarta: Rajawali Pers, 2004), h. 2.

${ }^{41}$ G.H. Jansen, Militant Islam. Terj. Armahedi Mahzar (Bandung: Pustaka, 1980), 47. Bandingkan dengan Nazih N. Ayubi, Political Islam: Religion and Politics in the Arab World (London and New York: Routledge, 1993).

${ }^{42}$ Adam Schwarz, A Nation in Waiting: Indonesia Search for Stability (Singapore: Talisman, 2008).

${ }^{43}$ Azyumardi Azra, Pergolakan Politik Islam dari Fundamentalisme, Modernisme hingga Post-Modernisme (Jakarta: Paramadina, 1996). Bandingkan dengan Azyumardi Azra, Konteks Berteologi di Indonesia Pengalaman Islam, h. 93.

${ }^{44} Y u s u f$ Qardawi, Membedah Islam "Ekstrem," terj. Alwi A.M, cet. 9 (Bandung: Mizan, 2001), h. 23.
} 
di suatu negara yang bukan Islam dan bukan negara asal Islam; atau atas kaum yang baru memeluk agama Islam atau orang yang baru bertaubat. Keempat, sikap kasar dan keras. Dalam hal ini tercermin dalam perkataan dalam berkomunikasi serta berdakwah, dan bersikap intoleransi terhadap sesama dan antara sesama umat beragama. Kelima, buruk sangka terhadap manusia. Artinya di sini adalah dalam memandang orang lain digunakan "kacamata hitam", menyembunyikan kebaikan mereka sementara membesarbesarkan keburukan mereka. Keenam, terjerumus ke dalam jurang pengafiran. Kondisi ini adalah puncak dari beberapa ciri-ciri ekstrem yang telah disebutkan di atas, sehingga hak kehormatan orang lain, jiwa dan harta orang lain sudah halal untuk dirampas dan diperlakukan dengan keras. ${ }^{45}$

Keempat adalah istilah "revivalis". Fazlur Rahman ${ }^{46}$ dan John L. Esposito ${ }^{47}$ adalah orang yang cendrung melabelkan kelompok Islam yang beraliran keras dengan istilah "Islam Revivalis". Hal ini menurut Rahman dan Esposito ditandai dengan, pertama, memiliki pandangan hidup yang komprehensif dan bersifat total. Artinya tidak ada pemisahan Islam dari kehidupan politik, hukum, dan masyarakat. Tanda keduanya adalah semua yang terkait dengan pengaruh lokal maupun yang terkait dengan global (Barat) harus ditolak, karena hal ini dianggap sebagai pengikis kemurnian Islam. ${ }^{48}$ Arti kata Islam hanya dikembalikan seperti yang terpraktikkan pada zaman Nabi dan sahabat dulu..$^{49}$ Terakhirnya adalah ditandai dengan sikap pengagungan kejayaan Islam pada masa lalu tanpa memperhatikan kondisi sekarang.

Oleh karena itu dalam konteks ini digunakan istilah Islam radikal dalam menelusuri genealogi, pemikiran, dan gerakan ormas Islam yang diduga beraliran keras. Radikal dalam konteks ini, tidak hanya sebatas kekerasan dalam bentuk fisik, seperti penyerangan, perusakan, pemukulan, dan lain sebagainya, tetapi kekerasan di sini juga dimasukan dalam bentuk

${ }^{45}$ Yusuf Qardawi, Membedah Islam "Ekstrem”, h. 29-45.

${ }^{46}$ Fazlur Rahman memberi istilah gerakan radikalisme Islam dengan sebutan gerakan neo-revivalisme atau neo-fundamentalisme, sebuah gerakan yang mempunyai semangat anti Barat. Lebih lanjut lihat Fazlur Rahman, Islam dan Modernitas: Tantangan Transformasi Intelektual (Bandung: Pustaka, 1995), h. 162.

${ }^{47}$ John L. Esposito, Islamic Threat, Myth or Reality? (New York and Oxford: Oxford University Press, 1992), h. 69.

${ }^{48}$ Barat dalam konteks ini dianggap oleh sebagian kalangan Muslim yang paling bertanggung jawab atas marjinalisasi Bangsa Timur dengan ide sekularismenya yang berdampak pada dekadensi moral Bangsa Timur, pandangan ini sepenuhnya menyatakan penolakan total terhadap Barat seperti yang ditunjukkan oleh Sayyid Qutb. Lebih lanjut lihat Ibrahim M. Abu Rabi', Intellectual Origin of Islamic Resurgence in the Modern Arab World (New York: State University of New York Press, 1996), h. 93-137. Informasi ini juga dikemukakan oleh Musa Ash'ari, Manusia Pembentuk Kebudayaan dalam Al-Qur'an (Yogyakarta: LESFI, 1992), h. 95.

${ }^{49} \mathrm{Hasan}$ al-Banna menyebut ajaran kelompoknya (al-Ikhwan al-Muslimun) dengan salafiyun yang artinya orang-orang terdahulu. Istilah ini secara teknis menunjukkan upaya mengikuti perilaku keagamaan yang didasarkan pada Al-Qur'an, Sunnah Rasul, dan praktik kehidupan orang-orang saleh terdahulu. Lihat Bahtiar Effendy dan Hendro Prasetyo, Radikalisme Agama (Jakarta: PPIM-IAIN, 1998), h. 7. 
simbolik yang terinfiltrasi dalam agitasi, provokasi, dan bahasa yang menaruh kebencian. Kenyataannya kekerasan itu secara umum berawal dari ungkap-ungkapan yang menyudutkan kelompok lainnya. Artinya dalam pembahasan ini, radikal yang dipakai adalah radikal yang telah diturunkan frekuensinya. Meskipun terlihat tidak terpotret dalam bentuk gerakan adu fisik, tetapi pernyataan yang telah bernada kebencian juga dianggap radikal dalam kajian ini.

Asumsi awal yang dijabarkan dalam pembahasan ini adalah bahwa Islam radikal bermula dari peristiwa tahkim antara pihak 'Ali bin Abi Talib dengan Mu'awiyah bin Abu Sufyan, sehingga muncul kelompok yang tidak menerima hasil keputusan tahkim tersebut. Pihak yang tidak menerima adalah potret orang yang kalah dan merasa terasing dari kelompok Islam mayoritas, sehingga hanya melalui kekerasan keinginan mereka dapat diwujudkan. ${ }^{50}$ Beranjak dari argumen ini akan ditelusuri perjalanan Islam radikal dalam tinjauan sejarah, baik yang terjadi di kawasan Asia Tenggara, Timur-Tengah, dan tempat lainnya, sekaligus menegaskan argumen peneliti bahwa kemunculan radikalisme Islam dalam kawasan dunia Muslim merupakan bagian dari ketersambungan sejarah.

Khaled Abou El Fadl dalam karyanya, The Great Theft: Wrestling Islam From the Extremists, membuktikan bahwa radikalisme dalam Islam adalah keberlanjutan sejarah, sekaligus menolak, bahwa radikalisme terputus dengan sejarah. El Fadel melalui karyanya ini mencontohkan adanya keterkaitan antara paham Wahhabisme dengan aksi teroris yang disponsori oleh jaringan terorisme internasional Al-Qaeda dan gerakan Taliban di Afganistan. Dalam kajian ini, terungkap bahwa paham Wahhabisme tidak hanya subur dan berkembang di tanah kelahirannya, tetapi ia juga tumbuh dan berkembang di negara-negara Muslim lain. ${ }^{51}$ Demikian juga halnya di Indonesia, paham Wahhabisme mempunyai akar-akar yang kuat, baik dalam bentuk paham keagamaan yang bersifat masif, maupun dalam bentuk gerakan yang dimanifestasikan dalam berbagai aksi kekerasan. Dalam kasus ini, dapat ditemukan bahwa pergerakan ini satu sisi memiliki semangat kembali kepada ajaran Islam murni, tetapi pada sisi lain dibarengi dengan semangat kekerasan. ${ }^{52}$ Model seperti ini yang menjadi persoalan, karena kondisi ini akan berkaitan dengan kelangsungan kehidupan yang heterogen di tengah perubahan sosial.

Kemudian menurut pandangan Azyumardi Azra, bahwa kemunculan radikalisme itu bukan hanya semata-mata dorongan keagamaan, melainkan didorong oleh situasi ekonomi, politik, budaya dan sosial. ${ }^{53}$ Agama hanya dijadikan sebagai pembenaran gerakan mereka. Dalam hal politik, contohnya ketika otoritas negara mulai melemah (masa transisi)

\footnotetext{
${ }^{50}$ Azyumardi Azra, Pergolakan Politik Islam dari Fundamentalisme, Modernisme, h. 111.

${ }^{51}$ Khaled Abou El Fadl, The Great Theft: Wrestling Islam from the Extremists (San Francisco: Harper Collins Publishers, 2005), h. 111.

${ }^{52}$ Khaled Abou El Fadl, The Great Theft: Wrestling Islam from the Extremists, h. 79.

${ }^{53}$ Azyumardi Azra, Menggapai Solidaritas Tensi antara Demokrasi Fundamentalisme dan Humanisme (Jakarta: Pustaka Panjimas, 2002), h. 43.
} 
setelah Orde Baru berkuasa lebih 30 tahun runtuh, maka terbuka peluang untuk mengekspresikan pemahaman keagamaan tanpa batas, seperti ungkapan pepatah Minangkabau "Sakali aie gadang, sakalian pulo tapian barubah", maksudnya setiap terjadi peralihan rezim, maka akan terjadi pula sebuah perubahan. Azra menambahkan dalam kasus Sumatera Barat, hal ini juga diakibatkan oleh euforia demokrasi, di samping dicabutnya Undangundang anti-subversi oleh Presiden BJ. Habibie. ${ }^{54}$

Selain dua pandangan di atas, pada konteks ini ada ruang menyatakan bahwa kemunculan radikalisme Islam di Sumatera Barat pasca Orde Baru memiliki keterkaitan dengan gerakan Paderi tempo dulu. Maksudnya kehadiran sejumlah ormas Islam baru, baik yang berskala lokal, dan nasional maupun berskala transnasional, ia sesungguhnya dimanfaatkan oleh lokal sebagai simbol gerakan dalam melanjutkan agenda gerakan Paderi yang telah tenggelam. Hal ini ditandai oleh semangat kelompok Muslim yang tergabung dalam HT, FPI, dan KPSI untuk menghidupkan kembali gerakan Paderi melalui usaha penegakan syariat Islam, memenuhi panggilan amar makruf nahi munkar serta pendirian Negara Islam. Pada tataran ini, gerakan Paderi dijadikan sebagai semangat perjuangan mereka. Lagi pula, komposisi kepengurusan HT, FPI, dan KPSI ada diisi oleh orang-orang yang memiliki keterikatan ideologi dengan Paderi, baik secara langsung maupun tidak langsung. Kelompok yang memiliki keterikatan secara langsung dengan Paderi, menamakan wadah mereka dengan sebutan Aliansi Paderi Indonesia (API). Sedangkan keterikatan yang tidak langsung, cukup menjadikan gerakan Paderi sebagai spirit perjuangan mereka. Atas dasar inilah dapat dikatakan bahwa keberadaan HT, Salafi, FPI, dan KPSI dimanfaatkan lokal sebagai wadah perjuangan.

Ditinjau dari sejarah dan perkembangan Islam pasca ditinggalkan oleh Muhammad, permasalahan radikalisme terus bergulir melintasi waktu yang dilaluinya. Dikaji lebih dalam, ternyata tercatat dalam sejarah bahwa gerakan al-Khawarij adalah awal radikalisme dalam Islam. Pada pembahasan ini dapat dibuktikan ketersambungan radikalisme Islam semenjak dari al-Khawarij hingga kontemporer, melalui genealogi, pemikiran, dan gerakannya yang terangkum dalam fase-fase sejarah Islam radikal.

\section{Gerakan Ormas Islam Garis Keras dalam Konteks Lokal: Penerapan Syariat Islam Sebagai Solusi Permasalahan Bangsa}

Permasalahan politik, sosial, ekonomi dan moral yang menimpa bangsa Indonesia pasca Orde Baru semakin waktu semakin meningkat. Kondisi politik yang tidak stabil, per-

\footnotetext{
${ }^{54}$ Menurut Azra kelompok ini mendambakan kembali berlakunya corak keislaman seperti generasi Nabi Muhammad dan para sahabatnya, karena pada masa ini Islam yang paling sempurna, sehingga Islam yang tampil sekarang harus dibersihkan dari kotoran seperti berbagai tambahan dan bid'ah dengan cara-cara radikal. Radikalisme religious-history kelompok ini diperkuat dengan pemahaman terhadap ayat-ayat Al-Qur'an dan Hadis secara harfiah. Lihat Azyumardi Azra, "Kelompok Radikal Muslim" Tempo, Edisi 26 Mei-1 Juni (2003), h. 52.
} 
ekonomian yang masih tidak menentu, kondisi sosial yang semakin pincang, serta dekadensi moral yang semakin rapuh, menyebabkan permasalahan bangsa semakin tidak terurus. ${ }^{55}$ Kemudian, kebijakan pemerintah juga cenderung berkiblat ke Barat. Seperti yang telah terjadi, bahwa kebijakan tersebut hanya menguntungkan kelompok tertentu, yang notabene adalah kalangan konglomerat, dan merugikan sebagian besar rakyat, sehingga penderitaan rakyat semakin tidak terselesaikan. Dampak seperti ini, juga dirasakan oleh masyarakat Sumatera Barat.

\section{Menggunakan Isu Lokal}

Dalam tinjauan sejarah, syariat Islam telah menjadi perhatian masyarakat Sumatera Barat. Munculnya falsafah "Adat Basandi Syarak, Syarak Basandi Kitabullah" merupakan bukti kepedulian masyarakat Sumatera Barat terhadap penerapan syariat Islam. Pandangan demikian telah menjadi kekuatan utama bagi masyarakat Sumatera Barat dalam menjalankan ajaran Islam pada setiap langkah kehidupan mereka. Namun demikian, seiring dengan perubahan orientasi, penerapan syariat menjadi dilematis. Menurut HT, Salafi, FPI, dan KPSI kepedulian terhadap penerapan syariat Islam seharusnya ditanggapi lebih serius oleh negara maupun masyarakat Muslim yang lebih luas. ${ }^{56}$

\section{Sosialisasi Pentingnya Tegak Syariat Islam}

Menyadari kesulitan untuk menyamakan pemahaman seluruh kaum Muslim tentang hukum Islam telah mendorong kelompok-kelompok Islam mengekspresikan pandangan mereka dalam nada yang relatif umum. Sejak jatuhnya pemerintahan Soeharto, pada dasarnya mereka hanya menyerukan kebutuhan untuk menerapkan syariat Islam dalam segenap aspek kehidupan. Hal itu dilakukan dengan berbagai cara, di antaranya melalui penyebaran gagasan dan pemikiran, tulisan dan perkataan.

\section{Berkolaborasi dengan Ormas Islam Lain}

Pada konteks ini, terjadi semacam peleburan beberapa ormas Islam dalam hal penerapan syariat Islam. Mereka saling memperkuat posisi dalam memperjuangkan pemberlakuan syariat Islam. Di samping itu, antara satu pengurus dan pengurus yang lain sering melebur

\footnotetext{
${ }^{55}$ Muhammad Khalid, Armando Salvatore, and Martin van Bruinessen (Eds.), Islam and Modernity Key Issues and Debates (Edinburgh: Edinburgh University Press, 2009), h. 47-49. Lihat juga Henry Munson. JR. Islam and Revolution in the Meddle East (New Haven: CT. Yale University Press, 1988), h. 79-81.

${ }^{56}$ Rozi Syaferi, wawancara, 22 September 2013, di Mesjid Nurul Iman Padang, juga dengan Elfi Syam, (Tokoh Salafi Sumatera Barat), wawancara, 26 Agustus 2013 di Mesjid Al-Hakim, di Padang dan dengan Albusyra (Ketua DPD I FPI Provinsi Sumatera Barat), wawancara, 28 Oktober 2013, di Candung Agam.
} 
dengan organisasi Islam lain. Tujuannya adalah agar mereka itu bisa mempengaruhi semua organisasi yang ada berjuang menegakkan syariat Islam, sekaligus mereka tidak mudah terdeteksi. ${ }^{57}$ Contohnya, Irfianda Abidin, di samping menjadi ketua di KPSI Sumatera Barat, dia juga menjadi pengurus di Majelis Tinggi Kerapatan Adat Alam Minangkabau (MTKAAM), Paga Nagari Sumatera Barat, dan Majelis Mujahidin Indonesia (MMI) pusat. ${ }^{58}$ Semua organisasi ini dapat digunakan untuk menyuarakan penerapan syariat Islam di Sumatera Barat. Dalam beberapa pertemuan, mereka saling menunjukkan kerja keras dalam merealisasikan agenda ini. Penerapan syariat Islam yang diperjuangkan oleh HT, Salafi, FPI, dan KPSI adalah merujuk kembali seperti apa yang pernah dilakukan oleh Nabi sesuai dengan zamannya. Sementara keinginan kelompok ini, menjadikan kondisi sekarang sama seperti zaman Nabi, tentu hal tersebut merupakan sesuatu yang sulit direalisasikan. ${ }^{59}$ Tetapi secara substansi tanpa menformalisasikan nampaknya akan mudah mendapat dukungan yang kuat.

\section{Menempuh Jalur Kultur dan Struktur}

Formalisasi syariat Islam menurut HT, Salafi, FPI, dan KPSI sudah menjadi suatu kewajiban dan mesti dijalankan apa adanya tanpa memperhatikan konteks sosial yang terjadi. Formalisasi seperti ini menurut Gus-Dur disebabkan oleh rasa kurang percaya diri ketika menghadapi "kemajuan Barat" yang sekuler. Oleh sebab itu jalan satu-satunya adalah dengan mensubordinasikan diri ke dalam konstruk Arabisasi yang diyakini sebagai langkah ke arah Islamisasi, padahal seperti yang diketahui bahwa Arabisasi bukanlah Islamisasi. ${ }^{60}$

Usaha penegakan syariat Islam di Sumatera Barat mulai memasuki wilayah kultur dan struktur. Semangat penerapan syariat Islam secara kultur dalam wilayah Sumatera Barat terlihat melalui berbagai kegiatan HT, Salafi, FPI, dan KPSI. Di antara kegiatan tersebut pertemuan ilmiah, ceramah, di berbagai tempat. Di samping itu mereka juga menggunakan selebaran, famplet, spanduk serta bulletin, baliho. Upaya penerapan syariat Islam secara kultur ini tersambung dengan gerakan Paderi pada abad ke-19, yang pernah menggerakkan agenda penerapan syariat Islam di Sumatera Barat. ${ }^{61}$

Sementara itu agenda perjuangan penerapan syariat Islam melalui jalur struktur adalah mendesak pemerintah daerah; Gubernur, Bupati/Wali Kota serta DPRD Propinsi

${ }^{57}$ Ibnu Aqil D. Gani, wawancara, pada tanggal 21 Oktober 2013. Jam. 14.00 WIB, di Ikur Koto Padang.

${ }^{58}$ Jell Fatullah, wawancara, pada tanggal 4 September 2013. Jam. 10.00 WIB, di Jln. Veteran Padang.

${ }^{59}$ Ahmad Syafi'i Ma'arif, Membela Kebebasan Beragama, h. 225.

${ }^{60}$ Abdurrahman Wahid, Islamku Islam Anda Islam Kita, xxxiii.

${ }^{61}$ Komentar Mas'ud Abidin tentang ketersambungan pemikiran dan gerakan ormas Islam kontemporer dengan pemikiran dan gerakan Paderi pada abad ke-19, http://masoedabidin. wordpress.com/2008/04/09/jejak-ulama-zuama-diminangkabau/. Diakses pada tanggal 15 November 2012. Jam. 14.00 WIB. 
dan DPRD Kabupaten/kota melahirkan Perda syariat Islam. Tuntutan seperti ini banyak menuai hasil, yaitu terwujudnya Perda syariat Islam di kabupaten/kota sebagai landasan kehidupan masyarakat. Perda yang telah lahir melalui jalur struktur ini, di antaranya tentang wajib baca tulis Al-Qur'an, bagi pelajar dan para pengantin, pengaturan jadwal hiburan-hiburan serta pelestarian terhadap nilai-nilai keagamaan yang melekat dalam tradisi masyarakat. Perjuangan penerbitan perda syariah ini diusulkan kepada para wakil rakyat (anggota DPRD) kabupaten/kota setelah diusulkan oleh pemerintah daerah. Partai yang mengambil kesempatan dengan situasi seperti ini adalah, PPP, PBB, PKS, PAN serta partai politik lainnya. Sebab apabila mereka tidak merealisasikan tuntutan rakyat ini, dapat dipastikan untuk Pemilu berikutnya, partai yang bersangkutan tidak mendapat dukungan lagi. ${ }^{62}$

\section{Penegakan Amar Makruf dan Nahyi Munkar: Tuntutan Ideologi}

\section{Amar Makruf dan Nahyi Munkar: Pengulangan Sejarah}

Kasus di Sumatera Barat aksi penerapan amar makruf dan nahyi munkar pernah dilakukan oleh gerakan Paderi pada abad ke-19. Gerakan amar makruf dan nahyi munkar ini sudah memasuki wilayah aksi dan tidak hanya sebatas tataran wacana saja. Gerakan yang pada awalnya bernuansa puritanisme kemudian berkembang menjadi gerakan aksi penerapan tuntutan memenuhi panggilan amar makruf dan nahyi munkar. Berbagai tindakan muncul pada agenda pelaksanaan amar makruf dan nahyi munkar ini, mulai tindakan pengusiran, pembakaran hingga sampai pembunuhan. ${ }^{63}$

Contoh aksi pengusiran terjadi pada saat pasukan Paderi berhasil menaklukkan suatu kampung. Warga yang tidak kuat menjalankan tuntutan kelompok Paderi, mereka dilarang lagi tinggal di sana. Mereka yang termasuk kategori ini tidak boleh tinggal lagi di kampung yang telah mereka tempati. Contoh aksi pembakaran terjadi pada saat pasukan Paderi mendatangi Surau Tuanku nan Tuo untuk diajak bergabung menegakkan amar makruf dan nahyi munkar secara tegas dan keras, namun ajakan demikian ditolak oleh Tuanku Nan Tuo. Sampai pada akhirnya Surau Tuanku Nan Tuo hangus dibakar oleh kelompok Paderi. ${ }^{64}$

Sedangkan contoh aksi pembunuhan adalah dalam kasus pelarangan tradisi bersugi daun sirih. Sebelum diterapkan gerakan pelarangan bersugi daun sirih, tradisi itu sudah menjadi simbol dan ukuran budi sopan santun masyarakat. Pepatah yang menyebutkan;

${ }^{62}$ Jel Fatullah, wawancara, 4 September 2013. Jam. 10.00 WIB, di Padang.

${ }^{63}$ Lihat Fakih Saghir, Surat Keterangan Shaikh Jalaluddin, h. 21-25. Dan Michael Laffan, The Makings of Indonesian Islam: Orientalism and, 44. Franz von Benda-Beckmann, Property in Social Continuity, Continuity and Change in The Maintenance of Property Relationship Trough Time in Minangkabau West Sumatera (The Hague-Martinus Nijhoff, 1979), h. 225-258.

${ }^{64}$ Fakih Saghir, Surat Keterangan Shaikh Jalaluddin, 21-25. Dan Michael Laffan, The Makings of Indonesian Islam: Orientalism and, h. 44. 
"Elok baso karano rokok, elok budi karano sirih" (Baik basa-basi karena rokok, dan baik budi karena sirih).$^{65}$ Tetapi bagi kelompok Paderi, tradisi seperti ini sudah menjurus perbuatan maksiat dan harus ditumpas. Kebetulan pada saat peraturan pelarangan makan sirih diberlakukan, ditemukan bibi Tuanku Nan Renceh (tokoh Paderi) sedang bersugi sirih. Menyikapi hal ini, Tuanku Nan Renceh langsung bertindak menerapkan gerakan amar makruf dan nahyi munkar dengan melakukan pembunuhan terhadap bibinya sendiri. ${ }^{66}$

\section{Menciptakan Kota Bersih dari Kemaksiatan}

Di Sumatera Barat, FPI dan KPSI cukup aktif menggerakkan amar makruf dan nahyi munkar. Menurut Albusyra (Ketua FPI Sumatera Barat), ${ }^{67}$ dan Irfianda Abidin (Ketua KPSI Sumatera Barat, ${ }^{68}$ bahwa kehadiran FPI dan KPSI di Sumatera Barat akan menjadi garda terdepan dalam memberantas kemaksiatan, sekaligus sebagai laskar dalam penegak syariat Islam melalui falsafah "Amar makruf, nahyi munkar". Sumatera Barat dari segi kultur merupakan wilayah yang terbebas dari bentuk perbuatan maksiat. Sesuai dengan falsafahnya "Adat Basandi Syarak, Syarak Basandi Kitabullah" merupakan cerminan kehidupan masyarakat. Artinya masyarakat Sumatera Barat tergolong masyarakat yang agamis, atau masyarakat yang komitmen terhadap ajaran agamanya. Oleh karena itu sudah semestinya Sumatera Barat memiliki pandangan yang sama dengan falsafah tersebut, sekaligus juga menunjukkan Sumatera Barat merupakan kawasan bebas maksiat. Merespon hal ini FPI dan KPSI hadir mengawal secara sungguh-sungguh terhadap pandangan demikian. Dalam konteks ini, FPI dan KPSI setiap malam Minggu melakukan razia terhadap tempat-tempat hiburan, seperti di Kota Bukittinggi dan Kota Padang. Dalam kegiatan itu mereka kadangkala menangkap pasangan muda-mudi yang diduga melakukan perbuatan tidak sopan, di sekitar Jam Gadang Bukittinggi, Ngarai Sianok dan di sekitar pinggir pantai Kota Padang. ${ }^{69}$

Dalam menjalankan gerakan amar makruf dan nahyi munkar, FPI dan KPSI melibatkan ormas lokal lainnya, seperti ormas Paga Nagari, ${ }^{70}$ dan ormas Libas. ${ }^{71}$ Ormas Paga Nagari dan ormas Libas ini juga memiliki concern yang sama dengan FPI dan KPSI ini. Perjuangan

${ }^{65}$ M. Letter, wawancara, pada tanggal 24 September 2013. Jam. 10.00 WIB, di Padang.

${ }^{66}$ Lihat Fakih Saghir, Surat Keterangan Shaikh Jalaluddin, 21-25. Lihat juga Michael Laffan, The Makings of Indonesian Islam: Orientalism and, h. 44.

${ }^{67}$ Albusyra, wawancara, 28 Oktober 2013. Jam. 16.00 WIB, di Lasi Agam.

${ }^{68}$ Irfianda Abidin, wawancara, 22 Oktober 2013. Jam. 11.30 WIB, di Mesjid Nurul Iman Padang.

${ }^{69}$ Albusyra, wawancara, 28 Oktober 2013. Jam. 16.00 WIB, di Lasi Agam.

${ }^{70}$ Paga Nagari adalah ormas lokal yang didirikan pada tahun 1998 di Jakarta oleh perantau Minang. Dia bertujuan untuk menerapkan syariat Islam sesuai dengan prinsip "Syarak Mangato, Adat Memakai”. Ormasi ini diketuai oleh Ibnu Aqil D. Gani. Dia juga termasuk pengurus inti di KPSI Sumatera Barat.

${ }^{71}$ Libas adalah ormas lokal yang didirikan pada 24 Mei 2004 di Padang. Tujuannya adalah untuk mencegah berkembangnya penyakit masyarakat. Ormas ini diketuai oleh Khairul Amri. 
terhadap pemberantasan perbuatan maksiat terus dilakukan dalam rangka membersihkan Sumatera Barat dari segala bentuk perbuatan yang bernuasa maksiat. Gerakan tersebut kadangkala diiringi dengan bentuk tindakan terhadap individu atau kelompok yang kedapatan melakukan kemaksiatan. Tidak hanya itu, FPI dan KPSI juga berhasil mendorong pemerintah daerah kabupaten/kota untuk mendukung agenda penegakan panggilan amar makruf dan nahyi munkar untuk menjadikan Sumatera Barat terbebas dari maksiat. ${ }^{72}$ Berkaitan dengan itu tekanan FPI dan KPSI terhadap parlemen provinsi semakin menguat untuk melahirkan peraturan daerah, sehingga melahirkan sebuah perda No. 11/2001 mengenai "penyakit masyarakat" (PEKAT). Penyakit masyarakat yang dimaksud dalam konteks ini adalah perjudian, prostitusi, dan penyalahgunaan obat bius. Kelahiran peraturan daerah ini lebih dominan nilai simboliknya, ketimbang nilai substansinya. ${ }^{73}$

\section{Penghentian Pembangunan Hotel Grand Kartini}

Gerakan amar makruf dan nahyi munkar FPI yang tidak kalah pentingnya adalah penghentian pembangunan Hotel Grand Kartini (HGK) di Kota Bukittinggi. Berbagai aktivitas penghentian pembangunan tersebut dilakukan berbagai model, mulai dari pemasangan spanduk hingga mendesak pihak pemerintah Kota Bukittinggi bertindak menghentikan pembangunan tersebut. Alasan yang mendorong FPI bersama dengan kelompok KPSI ini bertindak adalah pembanguan hotel di depan Mihrab Mesjid Nurul Haq akan memancing konflik SARA.

Pada tataran ini Abu Dzaki selaku Pembina KPSI pada tanggal 03 Pebruari 2012 di Bukittinggi menyatakan bahwa: Pertama, Ormas Islam baik FPI, KPSI maupun Majelis Mujahidin senantiasa berupaya menghentikan pembangunan Hotel Grand Kartini yang berada tepat di Mihrab Mesjid Nurul Haq, karena dapat menganggu ibadah umat Islam dan berpotensi memicu konflik SARA di Bukittinggi. Kedua, Ormas Islam, seperti FPI dan KPSI memasang dua spanduk yaitu di Hotel Grand Kartini dan di halaman Mesjid Nurul Haq. Spanduk tersebut bertuliskan, "Ormas Islam dan masyarakat Bukittinggi menolak keras pembangunan Hotel Grand Kartini (HGK)". Ketiga, Selain memasang spanduk, Ormas Islam ini juga mengultimatum pemilik Hotel Grand Kartini (HGK) untuk segera menghentikan pembangunan hotel tersebut karena jika terus dilanjutkan Ormas Islam, seperti FPI dan KPSI akan melakukan aksi lebih keras. Keempat, FPI dan KPSI mendesak Pemerintah Kota Bukittinggi segera mencabut izin pembangunan (IMB) HGK karena keberadaannya akan menganggu ketenangan ibadah jama'ah Mesjid Nurul Haq dan berpotensi memicu konflik antar umat beragama, karena pemilik Hotel Grand Kartini adalah China. Kelima, FPI dan KPSI mengajak seluruh umat Muslim berkumpul di Mesjid Nurul Haq pada pukul 13.30 WIB (setelah shalat Jum'at) untuk melakukan aksi membela Mesjid

${ }^{72}$ Khairul Amri, wawancara, 30 Oktober 2013. Jam. 14.30 WIB, di Mesjid Nurul Iman Padang.

${ }^{73}$ Dokumentasi DPRD Provinsi Sumatera Barat tahun 2001. 
Nurul Haq dari penghinaan pengusaha Hotel Grand Kartini. Keenam, untuk melancarkan upaya penghentian pembangunan melalui pengerahan massa ini, pihak FPI dan KPSI mengirim SMS ajakan kepada umat Muslim di Kota Bukittinggi untuk ikut bergabung dalam aksi demonstrasi membela Mesjid Nurul Haq dari penghinaan pengusaha atau pemilik Hotel Grand Kartini yang notabene adalah orang China. ${ }^{74}$

\section{Penutup}

Berdasarkan pembahasan di atas, dapat disimpulkan bahwa kemunculan radikalisme Islam semakin terbuka, ketika dihadapkan pada keinginan pengulangan periode sejarah Islam secara eksklusif. Dengan kata lain keinginan untuk menampilkan kembali periode kejayaan Islam tanpa disertai kajian yang komprehensif termasuk faktor dominan melahirkan kemunculan gerakan radikal. Dalam kesimpulan ini ditegaskan adanya ketersambungan ideologi dan gerakan HTI, Salafi, FPI dan KPSI di Sumatera Barat dengan gerakan Paderi. Oleh sebab itu, semakin tersambung ideologi dan gerakan HTI, Salafi, FPI dan KPSI dengan gerakan Paderi, maka semakin cepat kemunculan radikalnya di Sumatera Barat.

\section{Pustaka Acuan}

Abaza, Mona, “Generasi Baru Mahasiswa Indonesia di Al-Azhar”, Islamika, No. JanuariMaret. 1994.

al-Ashmawi, Muhammad Sa'id. Islam and the Political Orderi, Washington, DC: CRVP, 1994.

al-Ashmawi, Muhammad Sa'id. Ushul al-Syari’ah, cet. Ke-4. Kairo: al-Maktabah Madbuli al-Shagir, 1996.

Armstrong, Karen. Berperang Demi Tuhan, terj. Sutrisno Wahono dkk. Jakarta Bandung: Kerjasama Serambi dengan Mizan, 2001.

Ash'ari, Musa. Manusia Pembentuk Kebudayaan dalam Al-Qur'an. Yogyakarta: LESFI, 1992.

Azra, Azyumardi. Menggapai Solidaritas Tensi antara Demokrasi Fundamentalisme dan Humanisme. Jakarta: Pustaka Panjimas, 2002.

Azra, Azyumardi. Pergolakan Politik Islam dari Fundamentalisme, Modernisme hingga PostModernisme. Jakarta: Paramadina, 1996.

Bubalo, Anthony dan Greg Fealy. Jejak Kafilah: Pengaruh Radikalisme Timur Tengah di Indonesia. Bandung: Mizan.

Dobbin, Christine, Gejolak Ekonomi, Kebangkitan Islam, dan Gerakan Paderi Minangkabau 1784-1847. Depok: Komunitas Bambu, 2008.

Esposito, John L. The Islamic Theart Myth or Reality?. Oxford: Oxford University, 1992.

Garaudy, Roger. Fundamentalisme Islam dan Fundamentalisme Lainnya. Bandung: Pustaka, 1993.

${ }^{74} \mathrm{Abu}$ Dzaki, wawancara, 03 Februari 2013. Jam. 11.30 WIB, di Bukittinggi. 
Hadler, Jeffrey, Sengketa Tiada Putus Matriarkat, Reformisme Islam, dan Kolonialisme di Minangkabau. Jakarta: Freedom Institute, 2008.

Husaini, Adian. Hegemoni Kristen-Barat Dalam Studi Islam di Perguruan Tinggi. Jakarta: Gema Insan Press, 2006.

Jahroni, Jajang dan Jamhari. Gerakan Salafi Radikal di Indonesia. Jakarta: Grafindo Persada, 2004.

Kuntowijoyo. Identitas Politik Umat Islam. Bandung: Mizan, 1997.

Laffan, Michael, The Makings of Indonesian Islam: Orientalisme and the Narration of a Sufi Past. New Jersey: Princeton University Press, 2011.

Madjid, Nurcholis, Islam Agama Peradaban: Mencari Makna dan Relevansi Doktrin Islam dalam Sejarah. Jakarta: Paramadina, 1995.

Noer, Deliar, Islam Radikal Pergulatan Ormas-Ormas Islam Garis Keras di Indonesia. Jakarta: Teraju, 2002.

Qardawi, Yusuf. Membedah Islam "Ekstrem," terj. Alwi A.M, cet. 9. Bandung: Mizan, 2001.

Rabi', M. Abu. Intellectual Origin of Islamic Resurgence in the Modern Arab World. New York: State University of New York Press, 1996.

Rahman, Fazlur. Islam dan Modernitas: Tantangan Transformasi Intelektual. Bandung: Pustaka, 1995.

Rahmat, M. Imdadun, Arus Baru Islam Radikal: Transmisi Revivalisme Islam Timur Tengah ke-Indonesia. Jakarta: Erlangga, 2005.

Rais, Amien. Cakrawala Islam. Bandung: Mizan, 1995.

Roy, Olivier. The Failure of Political Islam. London: President and Fellows of Havard, 1994.

Schwarz, Adam. A Nation in Waiting: Indonesia Search for Stability. Singapore: Talisman, 2008.

Shihab, Alwi. "Agama dan Radikalisme," Majalah Pakar Vol. 1, No. 5-Januari, 2003.

Sivan, Emmanuel. Radical Islam, Medieval Theology and Modern Politics. New Haven: Yale University Press, 1985.

Tibi, Bassam Tibi, "Islamisme, Demokrasi, and the Clash of Civilization", dalam Chaider S. Bamualim (ed.), Islam \& The West. Jakarta: Pusat Bahasa dan Budaya UIN, 2003.

Turmudi, Endang. Islam dan Radikalisme di Indonesia. Jakarta: LIPI Press, 2005. 4.

Voll, John Obert. Islam: Continuty and Change in the Modern World. Boulder, Colorado: Westview Press, 1982.

Wahid, Abdurrahman. Islamku, Islam Anda, dan Islam Kita: Agama Masyarakat Negara Demokrasi. Jakarta: Yayasan Abad Demokrasi, 2011.

Waly, Tengku Muhibbuddin, Ayah Kami: Maulana Shaikh Haji Muhammad Waly al-Khalidi. Singapore: JBW Printers \& Binders PTE LTD, 1993.

Woodward, Mark R. (ed.). Jalan Baru Islam, Memetakan Paradigma Mutakhir Islam Indonesia, terj. Ihsan Ali Fauzi. Bandung: Mizan, 1999. 